\title{
Networks Sustainable Development in Global Competition
}

\author{
Margherita Corniani*
}

\begin{abstract}
The incoherence of the concept and its theoretical underpinnings have enabled the use of 'sustainable development' and 'sustainability' to become de rigueur for politicians and business leaders, sustainability is laden with so many definitions that it risks plunging into meaninglessness.

The issue is certainly a global one, and only global organizations are able to work on it and can promote it around the world. For these reasons it is interesting to understand in which way the global corporations, typically organized in global networks, are interested in this issue and what role they can play in the direction of sustainable development.

The real actual problem of the sustainable development, indeed, lays first of all in the concept of development and then, but just in a second moment, in the one of sustainability. What is development in a global economy where growth is no more the common rule and we hear the concept of de-growth? Some important answers to this question can be found in the actual discussion about the new role of capitalism in the global economy.
\end{abstract}

Keywords: Sustainability; Sustainable Development; Global Markets; Global Competition; Business Networks

\section{Sustainability and Sustainable Development}

"For most of the last couple of hundred years the environment has been largely seen as external to humanity, mostly to be used and exploited, with a few special areas preserved as wilderness or parks. Environmental problems were viewed mainly as local. On the whole the relationship between people and the environment was conceived as humanity's triumph over nature. This Promethean view was that human knowledge and technology could overcome all obstacles including natural and environmental ones. This view was linked with the development of capitalism, the industrial revolution and modern science. As Bacon, one of the founders of modern science, put it, "The world is made for man, not man for the world", (Hopwood et al. 2005).

The central idea underpinned by the concept of sustainability, and especially by the concept of sustainable development, is strictly concerned with the environment

*Associate Professor of Management, University of Milan-Bicocca (margherita.corniani@ unimib.it) 
and the focus is put on the critical aspects of the environment. This implies that humans, all around the world, have been exploiting the environment without really thinking about the future, because the future - in opinion to today's generation, is not their problem. This approach is definitely contradictory to the most cited interpretation of sustainable development promoted in Brundtland Report in 1987: "sustainable development is development that meets the needs of the present without compromising the ability of future generations to meet their own needs"1.

In fact, there are numerous critical aspects concerned by this definition, analysed and discussed by many authors. The first one is the Brundtland Report's need to directly define sustainable development, without thinking over the concept of sustainability or the one of development. Some explications of this choice can be found in the literature, particularly in seminal works of Maurice Strong who, speaking about the Stockholm Conference of 1972, of which he was Secretary General, wrote that:

$\square$ "The biggest single threat to the conference was the ambivalence, even antipathy, that developing countries felt toward the whole issue of development.

From the beginning, developing countries had regarded the West's concern with 'the environment' as just another fad of the industrialized countries; in their view pollution and environmental contamination were diseases of the rich, which could only divert attention and resources from their principal concerns: underdevelopment and poverty. They were understandably sensitive to the possibility that measures designed to protect the environment would impose new constraints on their development. Most of them would gladly exchange a little pollution for the benefits of economic growth. There was a growing movement to boycott the conference.

I knew the conference would fail if we couldn't persuade the developing countries to take part, and I knew they'd never agree to come unless their concerns were addressed. The draft conference agenda I'd inherited didn't even attempt to do so. 〈...>

The basic thesis, I said, is simple: environmental and economic priorities are intrinsically two sides of the same coin. Of course, there will be conflicts and trade-offs in particular cases, but I pointed out that it was, after all, the process of economic development that has an impact on the environment, both positively and negatively. Only through better management, therefore, can the basic goals of development be achieved to improve the lives and prospects of people in environmental and social as well as economic terms. My new agenda recognized that national priorities were dependent on the stage of development currently attained and would therefore vary. The key was to insist that the needs of developing countries would best be served by treating the environment as an integral dimension of development, rather than as an impediment" (Strong 2000).

The Stockholm Conference planners went on to redefine sustainability as sustainable development and the Brundtland Report followed this path. 
Many other criticisms then emerged in reference to this definition, regarding other two key-words in particular: 'development' and 'needs'.

Considering the term 'needs', the main critics can be summarized in two areas: who's needs? Which needs? Answering the first question, the point is to consider if the needs defined in the Brundtland definition must be considered simply as the human needs or different type-like needs. Some theorists have moved the debate from needs to rights: in this way the emphasis on both human and non-human rights pushed the discussion regarding the sustainability towards other more 'orthodox' concerns of social sciences: questions of power, distribution and equity (Mason 1999; Barnett 2001; Martinez-Alier 1995).

When it comes to the 'need' identification, someone asks if today's needs coincide with the needs of future generations. In fact, in the same historical moment, in different countries and in different economic contexts, people may actually feel different needs, and now we don't know, even if it is possible to imagine how the needs of future generations may look like in just few years from now (Redclift 2005).

\section{Development and Sustainability}

Over the concept of development there is also a wide discussion and a total disagreement, probably rearranged by the prevalent sentiment that the central point of view regarding this subject is the experiential one, i.e. the kind of development we are all used to.

Economics came to be the dominating issue of human relations with economic growth, defined by increasing production, as the main priority. This was seen as the key to humanity's well-being and, through growth, poverty would be overcome: as everyone floated higher those at the bottom would be raised out of poverty. (Hopwood et al. 2005; Douthwaite 1992).

口 "Sustainable development raises questions about the post-war claim, that still dominates much mainstream economic policy, that international prosperity and human well-being can be achieved through increased global trade and industry. It recognizes that past growth models have failed to eradicate poverty globally or within countries, 'no trends, no programmes or policies offer any real hope of narrowing the growing gap between rich and poor nations" (WCED, 1987). This pattern of growth has also damaged the environment upon which we depend, with a 'downward spiral of poverty and environmental degradation' (WCED, 1987). Brundtland, recognizing this failure, calls for a different form of growth, 'changing the quality of growth, meeting essential needs, merging environment and economics in decision making' (Hopwood et al. 2005; WCED 1987; Reid 1995; Moffat 1996; Sachs 1999).

The incoherence of this concept and its theoretical underpinnings have enabled the use of 'sustainable development' and 'sustainability' to become de rigueur for 
politicians and business leaders, but as the Workshop on Urban Sustainability of the US National Science Foundation (2000) pointed out, sustainability is "laden with so many definitions that it risks plunging into meaninglessness, at best, and becoming a catchphrase for demagogy, at worst. [It] is used to justify and legitimate a myriad of policies and practices ranging from communal agrarian utopianism to large-scale capital-intensive market development" (Hopwood et al. 2005).

Another important aspect to consider about the concept of development, is the qualitative dimension of this development, contrasting with a quantitative approach which is not able to explain different qualitative characteristics of the development. GDP is used by statistical offices to measure the development level of nations, but this indicator is unable to explain both the qualitative kind of the development and the perspective ability to grant this development. GDP can describe, in a very synthetic way, the economic output of a region, or of a State, but it does not explain at all the possible evolution of this region or State as for the development and sustainability.

Theories employ organismic metaphors restricted to only humanly mediated transactions across the organization-environment boundaries, ignoring the myriad ecosystem service transactions that ultimately keep the organizations alive. How many could organizations exist in the absence of oxygen production, fresh water supply, or fertile soil? The disassociation intellectually disconnects organizations from the ultimate sources of life-the sun, photosynthesis, biodiversity, food chains, and biogeochemical and nutrient cycles. In a manner not dissimilar to neo-classical economics, this disassociation leads the organizational theorists to employ injudicious assumptions, impossibility theorems, and fallacies of misplaced concreteness (Gladwin et al. 1995; Daly, Cobb 1989).

In this sense some authors considered weak sustainability as a kind of sustainability that sees natural and manufactured capital as interchangeable with technology (Daly, Cobb 1989). On the other hand, strong sustainability criticizes this approach, pointing out that human made capital cannot replace a multitude of processes retained vital to human existence such as the ozone layer, photosynthesis or the water cycle, etc. This debate between strong and weak sustainability is, however, conducted mainly around environmental issues rather than taking account of socio-economic consequences.

Traditional economic theory assumes that all input factors of the production process may be translated into monetary units, implying that they may also be substituted completely. Thus, the economic capital may very well substitute social capital and natural capital (Mäler 1990). Daly (1991), however, points out that not all kinds of natural capital can be substituted by economic capital (Dillick, Hockerts 2002).

Some authors pointed out that there are many different approaches to sustainable development and in all these approaches corporations and governments have their specific role. For example during the '70 (Schumacher 1973) many researchers were concerned about people, and convinced that the economy should be run 'as if people mattered', often implying that small and local is more sustainable than large and global, where small is privately owned and operating in a market economy, but, by the ' $80 \mathrm{~s}$, global markets have shown that we cannot close boundaries that are now open. So there is a fundamental divide between the supporters of the status quo and a transformation in their concept of and approach to sustainable development. The supporters of the status quo approach see the change through the management, 
top down and incremental, of the existing structures of decision-making. In the transformation view change will be realized mainly through political action working both in and outside the existing structures. At present the sustainable development discourse is dominated by the managerial outlook (Hopwood et al. 2005).

Certainly the Brundtland definition of sustainable development has its limitations, and maybe, the most important one is that it is not precise at all. Paradoxically, it fits with everything and with nothing at the same time.

" "Sustainable development is a term that everyone likes, but nobody is sure of what it means. 〈...> "While not vacuous by any means, this definition was sufficiently vague to allow for a broad consensus. Probably that was a good political strategy at the time - a consensus on a vague concept was better than disagreement on a sharply defined one. By 1995, however, this initial vagueness is no longer a basis for consensus, but a breeding ground for disagreement. Acceptance of a largely undefined term sets the stage for a situation where whoever can pin his or her definition on the term will automatically win a large political battle for influence over our future" (Daly 1996).

In the 1980's, the re-emergence of market economics and neo-liberal policies, with the measurement of sustainability, clearly marked a watershed for environmental politics. Increasingly 'sustainability' was detached from the environment, and environmental sustainability was mixed with wider questions of equity, governance and social justice, in order to shift political discussion to different quarters (Redclift 2005; Dempsey et al. 2011).

\section{Networks Sustainable Development in Global Competition}

Subsequently to the Brundtland Report and all the critical comments it has caused, the connections between economic, social and environmental issues implied by the sustainable development concept became more widely accepted and the Rio Summit in 1992 acknowledged the links between these three dimensions of the problem: "while there has been extensive work on all three problems over the past four decades, it was only the 1992 Earth Summit in Rio that brought the widespread acceptance of politicians, NGOs and business leaders that none of the three problems can be solved without also solving the other two (Dillick, Hockerts 2002; Keating 1993).

In fact, what became clear to all the actors involved in the issue analysis is that sustainability and sustainable development are actually global issues, influencing the whole world. The main problem with this global concept, indeed, is the fact that mostly each aspect of the problem cannot be resolved by one nation or one NGO alone, but implies the intervention of other nations and other NGO's. This point was clear in the Rio Earth Summit and it is still clear today. But we are still discussing about it and not a lot has actually been done to find out global solutions to the "problems" arising from the sustainable development discussion. 
The issue is indeed a global one, only global organization are able to work on it and can impose it around the world, even on nations and NGOs, or even better, with the local help of nations and NGOs.

For these reasons it is interesting to understand to which extent the global corporations, the only global organization active in the world, are really interested in this issue and what role they can play in the direction of sustainable development. Certainly, global corporations are linked to local territories for better or for worst but they are also able to live countries and move around the world searching for better places where to do their business (Garbelli 2002). Indeed their influence by staying in a territory or by looking for new territories has great impact on the nations and on all the economic, social and environmental development indicators.

The issues of sustainable development must thus be analysed and examined in depth also in the global corporation perspective, in order to understand how global corporations can be interested in this issue and can implement it all around the world.

Corporations have many objectives to reach, but certainly the basic one is the profit and only around and after this objective all the others can be progressively achieved. That's why even the concept of sustainable development must be declined in this perspective and must be clearly linked to the profit and not generally related to an economic perspective, which certainly is related to sustainable development and to environmental and social issues.

In fact, each single business resides in an interdependent network that includes economic, environmental, social and ethical principles, where the actions of one organization have the ability to influence the whole network. Sustainability is thus a more inclusive concept than single business actions, and for this reason there is a need to think about the effect within the global context caused by the activities in which businesses engage (Collins et al. 2007).

Global networks, the organisational form global corporations operating in global markets, are based on business relationships between corporations, which allow corporations to control their activities all around the world. In creating their networks, global corporations look for profit, and sustainable development issues can be included in their objectives if they can find out a connection between pursuing sustainable development and the profit issues for the network itself.

$\square$ "Whereas in the mid-1990s local authorities were probably the
most active players trying to implement sustainable development, the
focus has recently shifted strongly towards business as a major actor.
Although it is to be commended that managers accept their
responsibility for environmental and social issues, their interpretation
of the 'business link to sustainable development' is also worrying. In
their quest to find 'a single concept, perhaps a single word to sum up
the business end of sustainable development" (WBCSD, 2000) most
firms have opted for eco-efficiency as their guiding principle” (Dillick,
Hockerts 2002, De Simone, Popoff 1997).

In the financial markets, the ESG (Environment, Social, Governance) model has become a widely accepted standard to measure the corporate sustainability for investment purposes. While there are significant methodological differences between the different corporate sustainability indexes and rankings depending on 
the issuing organization, the main cornerstones of the model are widely recognised. The Sustainable Competitiveness Index is based on the adaption of the ESG model to the country level, with adjustments to fundamental pillars and indicators to measure sustainability - based competitiveness of a country. A distinctive difference between countries and corporations is that corporations are mobile. Countries are bound within their frontiers, and therefore depend, for good or for worse, on geographical and climatic environment within their given physical boundaries. The environmental component has therefore been divided into two separate field of competitiveness: the Natural Capital, and Resource Intensity, Sustainable Innovation and Social Cohesion, where the Natural Capital stands for availability of resources and Resource Intensity for the efficient use of available resources (Solability 2013a).

The sustainable competitiveness index proposed by Solability is based on many other indexes, including the GDP of nations. But in this perspective, GDP is considered as an index which can be influenced by sustainable competitiveness and not the opposite, i.e. the evidence of a sustainable development already reached by a nation or a region.

Thus, before than in a generic sustainable development, global networks are interested in developing a sustainable competitiveness, i.e. a kind of sustainable competitive behaviour which could be able to allow competitive position for the network in the short, medium and even long term. This is the sustainability development issue, which can be understood and followed by global networks. But even nations, in their local perspective are interested in this issue because their development and their sustainable development (in the economic, social and environmental dimensions) depend on business networks choices and on their willingness to stay and develop a territory.

\section{Opportunities and Costs of Sustainable Development for Business Networks}

"Manufacturing is the backbone of industrialised society. Industrialisation of countries, since the beginning of the industrial revolution, has taken place through manufacturing. At the start of the industrial revolution, it was based on 'small' networks within limited geographical domains and later on, on networks that exceeded first regional and, hence, national boundaries.

The first industrial revolution and consequent progressive world industrialisation, respectively, started and enabled long-lasting economic growth, then development, based on competitive innovation. This has led to historically unprecedented economic growth and development. Such growth has affected and, in turn, been affected by, the economy, society, environment and technology context" (Jovane et al. 2008).

In the famous paper published by Harvard Business Review in 1995, Porter and van der Linde discussed on the costs of 'being green or competitive' for corporations. "The prevailing view is that there is an inherent and fixed trade-off: ecology versus the economy. On one side of the trade-off are the social benefits that arise from strict environmental standards. On the other are industry's private costs for prevention and clean-up costs that lead to higher prices and reduced competitiveness". 
The costs of regulations, in order to obtain a virtuous behaviour from corporations, is thus imposed by the political system on a local territory and paid by corporations acting on that territory, while increasing their operational costs and reducing their competitiveness. But this static view does not consider: the dynamism of political forces (which change their policies about different kinds of regulations) not the dynamism of corporations both in two directions, delocalisation and innovation policies. Following delocalisation, corporations chose to move their activities looking for lower costs (environmental and social regulations) allowing them to be competitive, compared to other corporations which, naturally, will follow the same path, reducing the competitive advantage of such cost reductions. On the other side, the innovation path moves in another direction, introducing the idea of re-use and efficient use of resources. It means that corporations instead than continuing with the same processes in delocalised areas where polluting processes are actually allowed (or not considered) and labour regulations are more 'open', considers the hypothesis of changing their processes in order to be more efficient.

This efficiency principle is the basic idea introduced by the scientific management theory at the beginning of the XX century by Frederick Taylor (Taylor 1911) and implemented by Henry Ford in his plants of mass production, then by Alfred Sloan in GM, trying to follow Ford's path with a differentiated system of productions, and finally by Toyota with new technologies in order to obtain variety and low costs of standardisation. The common point in these productive and competitive systems has been the search for efficiency, i.e. obtaining the maximum results with the minimum efforts. The central question is then what is result and what effort. Ohno (1978), guiding Toyota during the '70s explained that all the time and goods wasted were reducing efficiency and he studied his processes in order to grant the minimum waste for any item. "When scrap, harmful substances, or energy forms are discharged into the environment as pollution, it is a sign that resources have been used incompletely, inefficiently, or ineffectively. Resource inefficiencies are most obvious within a company in the form of incomplete material utilization and poor process controls, which result in unnecessary waste, defects, and stored materials" (Porter, van der Linde 1995).

At the same time, another important manager proved that even in restricted conditions corporations must be able to operate, finding out the way to do it at the best, using all the possible resources. Lawrence Miles in GE, developed the value methodology in order to grant the production process during 2nd WW when GE was lacking materials and specialised workers. Miles taught to corporations to use all the disposable materials and product, and in this perspective, it becomes possible to reduce pollution and re-use the wastes in an economical manner.

These two different points of view demonstrate that in the search for cost minimisation (to gain a so called 'internal competition') resides the answer for a new perspective for corporations capability to deal with sustainable development issues and to face the consequent changing and instable regulatory systems all around the world. The answer is considering pollution, workers conditions and social issues as by-products of corporations, which costs must be paid before or after by the corporations, unable to keep strong relationships with territories and communities.

If pollution and social negative consequences of corporations behaviour are considered a by-product of corporations activities they become exactly like waste, something that must be reduced, in order to be efficient and competitive. 
Corporations must find out the way to re-use their polluting externalities, to recreate the resources they use, and to minimize the by-products, in order to reduce their costs and, by consequence, this will create important opportunities for the long term relationships with territories and, particularly, with the stakeholder communities around them. "This enhanced resource productivity makes companies more competitive, not less" (Porter, van der Linde 1995).

A common example of this principle is the closed loop supply chain, were a supply chain integrate the waste produced, re-using it in its processes (Gandolfo, Sbrana 2008).

This perspective is not at all new but it implies a different focus on resources and on innovation dynamism of corporations. Instead of looking to convince political parties to regulate corporations behaviour following opportunistic paths, the idea is to change dramatically the focus from costs of sustainable development to opportunities of sustainable development, as many global corporations have done in the last 40 years.

"Viewing defects as a sign of inefficient product and process design -not as an inevitable by-product of manufacturing- was a breakthrough. Companies now strive to build a quality into the entire process. The new mind-set unleashed the power of innovation to relax or eliminate what companies had previously accepted as fixed trade-offs" (Porter, van der Linde 1995).

"Sharp's CSR has its roots in its Business Philosophy and Business Creed. Sharp divides its CSR activities into four large categories (1. Offering innovation through business activities, 2. Harmony with Society and collaboration with partners, 3. Creation and innovation of corporate culture, 4. Basic social responsibility: Corporate governance, Internal control, Risk management, Compliance, Dividend payment, Tax payment, etc.) and pursues them while engaging and communicating with stakeholders. The Sharp Group Charter of Corporate Behavior and the Sharp Code of Conduct serve as the basis for all of these activities. All directors and employees of Sharp Group companies act appropriately and in a sincere manner in line with these guidelines, in order to make Sharp the kind of company society needs" (Sharp Sustainability Report 2014).

口 "As a company and a worldwide system that includes our bottling partners, Coca-Cola is committed to creating value for the communities we proudly serve and the planet we all share. Sustainability is at the heart of our business. And as a business, we know that sustainability efforts are themselves only sustainable when they help our enterprise grow and prosper. Indeed, we believe this work must be integral to our mission of refreshing the world, inspiring moments of optimism and happiness, creating value and making a difference. As a result, we've chosen to focus our leadership on three areas of fundamental importance to our business areas where we believe we have the best opportunity to make a lasting positive difference. We call them the "Three Ws": Women, Water and WellBeing. We also continue to implement sustainability programs across 
other areas of our operations" (Coca-Cola Sustainability Report 201314).

The transformation of the costs of sustainable development into opportunities for corporations is forced by some specific connections which explain why, until now, one of the most common interpretations for sustainable development is the expectation for a regulatory policy from governments in the areas of environment, society and economy.

The way through more competitive processes leads to innovations, value analysis for innovation, for finding new and different solutions. But "companies, in turn, oppose and delay regulations instead of innovating to address them" because "policy makers, business leaders, and environmentalists have focused on the static cost impacts of environmental regulation and have ignored the more important offsetting productivity benefits from innovation. As a result, they have acted too often in ways that unnecessarily drive up costs and slow down progress on environmental issues" (Porter, van der Linde 1995).

The final result is that "the whole process has spawned an industry of litigators and consultants that drains resources away from real solutions" (Porter, van der Linde 1995).

The problem is then still there: governments change and thus sustainable development regulations change, while global corporations are able to delocate in the world, choosing the best place where to carry out their activities. Sustainable development costs and opportunities are strictly linked with the costs of reputation, to create and impose a corporate image well accepted and trusted by the various stakeholders.

"Economic sustainability requires firms to manage several types of economic capital: financial capital (i.e. equity, debt), tangible capital (i.e. machinery, land, stocks) and intangible capital (i.e. reputation, inventions, know-how, organizational routines). A company ceases to exist once no economic capital is left, but in reality a company will become unsustainable long before" (Dillick, Hockerts 2002).

In global markets, with global competitors, the costs for sustainable development become costs for competitiveness or, more exactly, costs for economic sustainability of competitiveness (Garbelli 2005).

Another important cost of sustainable development concerns financial issues of corporations, particularly important for global corporations, exposed to open markets and to the global financial community. For this reason, financial "clean" eco-friends (i.e. funds investing only in clean activities) developed in the recent decades. The underlying principle is that finance is risky and that it is not worthy to invest in businesses not yet able to grant a sustainable development behavior certificated by some external party, in order to move away the responsibility from the sustainability scandals. This is the consequence of the common interpretation of sustainable development as a formal reaction to strict regulatory policies, in order to maintain a clean reputation and be able to attract huge amount of investments. This interpretation is far more related to the sustainability rather than to the development, being oxymoronic with the traditional financial perspective riskreturn.

In this perspective, the most important problems global corporations are facing are located in the area of sustainability measurement within and for corporations, with the aim to translate the sustainability issues into an economic language, 
helping corporations to deal with this specific and pervasive element of their role in the economy and in the world itself.

As far as measurement is concerned, we can thus observe that the corporations focus has moved from shareholder theory to stakeholder theory, from BSC (balance scorecard) (Kaplan, Norton 1992) to TBL (triple bottom line) (Elkington 1997) moving the analysis focus from strict economic issues to wider aspects, introducing also environmental and social issues (Hubbard 2009).

\section{Emerging Issues}

Around twenty years ago, authors studying the issues related to sustainable development, asked a fundamental question: 'How do we wish to live and what is the role of organisations in such living?'

"Despite promising work emerging from scholars associated with the Academy's Organizations and Natural Environment Interest Group, most management theorizing and research continues to proceed as if organizations lack biophysical foundations. Organic and biotic limits in the natural world are excluded from the realm of organizational science. <...> Our own content analysis suggests that sustainable development is a process of achieving human development (widening or enlarging the range of people's choices; United Nations Development Programme, 1994) in an inclusive, connected, equitable, prudent, and secure manner. Inclusiveness implies human development over time and space. Connectivity entails an embrace of ecological, social, and economic interdependence. Equity suggests inter-generational, intra-generational, and interspecies fairness. Prudence connotes duties of care and prevention: technologically, scientifically, and politically. Security demands safety from chronic threats and protection from harmful disruption" (Gladwin et al. 1995).

Introducing the concept of sustainability into the organizational thinking has implications for business strategy, which affects the way the firms measure their performance. 'Sustainability' can mean many things to organizations. Indeed, many organizations do not distinguish between environment and sustainability while other organizations equate sustainability with economic sustainability, that is, with consistent levels of economic growth (Bansal 2002). Strategically, organizations can see sustainability as a compliance issue (something that has to be done because it is law), a cost to be minimized (something to spend the minimum amount on) or an opportunity for competitive advantage (something that leads to opportunities). There is some evidence that organizations follow an evolutionary path in their attitudes and behaviours - from compliance to competitive advantage (Hart 1995; Florida 1996): a path that mirrors their responses to environmental management issues (Hubbard 2009).

As it emerges, the real problem with the issue of sustainable development from a managerial perspective is what the development actually is for corporations. Sustainability development is first of all the business of global corporations, the only organisations able to look at the world really in a global perspective, i.e. knowing that their success will depend on their ability to be competitive and not by the protections exerted by local government through a set of regulations and competitive protectionisms. As long as in the world will be possible to isolate areas where sustainable development is not considered an issue, this areas will continue 
to be places where corporations and other countries will discharge their pollution and all what is not considered sustainable in their home countries. But global corporations are more powerful than Nations-States (Bisio 2005), imposing their behaviour all around the world, by moving capital, knowledge, labour and products (Brondoni 2011).

"Sustainability management performance is not only about protecting the reputation, maintaining customer and stakeholder trust, and controlling operational cost. Sustainable corporate development and sustained business success also involves identifying and actively pursuing new business opportunities, i.e. incorporating sustainability not only in management systems, but also in strategic business development decision-making. Successful implementation of sustainable business development strategy beyond reputation protection and cost control requires two main stages: (a) Identification of future trends, risks, and opportunities arising from those risks; (b) Allocating adequate resources and making the right investments, taking into consideration competitor behaviour and market trends" (Solability 2013b).

Sustainable development depends thus on the capability of corporations to be competitive in the long term, in a global perspective.

\begin{abstract}
$\square$ "We can begin our analysis of these different discourses by returning to essentials. With hindsight we can see that each scientific problem resolved by human intervention using fossil fuels and manufactured materials is conventionally viewed as a triumph of management, and a contribution to economic good, when it might also be seen as a future threat to sustainability. In the 1970s there was a fear that our major environmental problems would be associated with resource scarcities. At the beginning of the 21st century we are faced by another challenge: that the means we have used to overcome resource scarcity, including substitution of some natural resources, and 'cleaner' environmental products and services, may have contributed to the next generation of environmental problems. This realization provides an enormous challenge to social scientists and others who value critical thinking, and who acknowledge the centrality of the environment and sustainability in a radical programme for bringing about substantial changes in late capitalism" (Redclift 2005; Meadows et al. 1972; Huber 2000)
\end{abstract}

The real actual problem of the sustainable development, indeed, lays first of all in the concept of development and then, but just in a second moment, in the concept of sustainability. What is development in a global economy where growth is no more a common rule for most economies and where economists are starting to speak about slow growth (like Jacques Attali and the Positive Economy, or Porter and Kramer in 2011 with "Creating Shared Value") still ignoring which rules can apply to de-growth?

Some important answers can be found in the actual discussion about the new role of capitalism in the global economy as it has recently been pointed out by many important authors (Piketty, Lambin 2012) and less recently, in a sociological perspective, by other authors asking themselves essential questions about risk (even 
ecological and capitalistic) in the actual global society (Beck 2006; Beck 1992; Giddens 1999).

\section{Bibliography}

Bansal Pratima (2002) The Corporate Challenges of Sustainable Development, Academy of Management Review, vol. 16, n. 2, pp. 122-131.

http://dx.doi.org/10.5465/AME.2002.7173572

Barnett Jon (2001) The Meanings of Environmental Security, Zed, London.

Beck Ulrich (2006) Living in the world risk society. A Hobhouse Memorial Public Lecture given on Wednesday 15 February 2006 at the London School of Economics, Economy and Society, Vol. 35, n. 3, pp. 329-345.

http://dx.doi.org/10.1080/03085140600844902

Beck Ulrich (1992) The Risk Society: Towards a New Modernity, Sage, London.

Bisio Luca (2005) Global Companies and Global Regulation, Symphonya. Emerging Issues in Management (symphonya.unimib.it), n. 1, pp. 87-101.

http://dx.doi.org/10.4468/2005.1.07bisio

Brondoni Silvio M. (2011) Global Networks, Knowledge Management and World Cities, Symphonya. Emerging Issues in Management (symphonya.unimib.it), n. 1, pp. 7-18.

http://dx.doi.org/10.4468/2011.1.02brondoni

Collins Eva, Lawrence Stewart, Pavlovich Kathryn, Ryan Chris (2007) Business Networks and the Uptake of Sustainability Practices: the Case of New Zealand, Journal of Cleaner Production, vol. 15, pp. 729-740.

http://dx.doi.org/10.1016/j.jclepro.2006.06.020

Daly Herman E. (1991) Steady-State Economics, Island, Washington, DC.

Daly Herman E., Cobb John B. (1989) For the Common Good: Redirecting the Economy Toward Community, the Environment, and a Sustainable Future, Beacon Press, Boston.

Daly Herman E. (1996) Beyond Growth: The Economics of Sustainable Development, Beacon Press, Boston.

Dempsey Nicola, Bramley Glen, Power Sinéad, Brown Caroline (2011) The Social Dimension of Sustainable Development: Defining Urban Social Sustainability, Sustainable Development, vol. 19, pp. 289-300.

http://dx.doi.org/10.1002/sd.417

DeSimone Livio, Popoff Frank (1997) Eco-Efficiency: the Business Link to Sustainable Development, MIT Press, Cambridge.

Dyllick Thomas, Hockerts Kai (2002) Beyond the Business Case for Corporate Sustainability, Business Strategy and the Environment, vol. 11, pp. 130-141.

http://dx.doi.org/10.1002/bse.323

Douthwaite Richard (1992) The Growth Illusion, Green, Bideford.

Elkington John (1997) Cannibals With Forks: the Triple Bottom Line of 21st Century Business, Capstone, Oxford.

Florida Richard (1996) Lean and Green: the Move to Environmentally Conscious Manufacturing, California Management Review, vol. 39, n. 1, pp. 80-105.

Gandolfo Alessandro, Sbrana Roberto (2008) Reverse Logistics and Market-Driven Management, Symphonya. Emerging Issues in Management (symphonya.unimib.it), n. 2, pp. 28-40.

http://dx.doi.org/10.4468/2008.2.03gandolfo.sbrana

Garbelli Maria Emilia (2005) Product Differentiation Costs and Global Competition, Symphonya. Emerging Issues in Management (symphonya.unimib.it), n. 1, pp. 66-86.

http://dx.doi.org/10.4468/2005.1.06garbelli 
Garbelli Maria Emilia (2002) Over-Supply and Manufacturing Localization, Symphonya. Emerging Issues in Management (symphonya.unimib.it), n. 1, pp. 112-126.

http://dx.doi.org/10.4468/2002.1.10garbelli

Giddens, Anthony (1999) Runaway World: How Globalization is Reshaping Our Lives, Profile, London.

Gladwin Thomas N., Kennelly James J., Krause Tara-Shelomith (1995) Shifting Paradigms for Sustainable Development: Implications for Management Theory and Research, The Academy of Management Review, vol. 20, n. 4, pp. 874-907.

Hart Stuart L. (1995) A Natural-Resource-Based View of the Firm, Academy of Management Review, vol. 20, pp. 986-1014.

Hopwood Bill, Mellor Mary, O’Brien Geoff (2005) Sustainable Development: Mapping Different Approaches, Sustainable Development, vol. 13, pp. 38-52.

http://dx.doi.org/10.1002/sd.244

Hubbard Graham (2009) Measuring Organizational Performance: Beyond the Triple Bottom Line, Business Strategy and the Environment, vol. 18, pp. 177-191.

http://dx.doi.org/10.1002/bse.564

Huber Joseph (2000) Towards Industrial Ecology: Sustainable Development as a Concept of Ecological Modernisation, Journal of Environmental Policy and Planning, vol. 2, n. 4, pp. 269285.

http://dx.doi.org/10.1080/714038561

Jovane Francesco, Yoshikawa H., Alting L., Boe C.R., Westkamper E., Williams D., Tseng M., Seliger G., Paci A.M. (2008) The Incoming Global Technological and Industrial Revolution Towards Competitive Sustainable Manufacturing, CIRP Annals - Manufacturing Technology, vol. 57, pp. 641-659.

http://dx.doi.org/10.1016/j.cirp.2008.09.010

Kaplan Robert S., Norton David P. (1992) The Balanced Scorecard, Harvard Business School, Boston.

Keating Michael (1993) The Earth Summit's Agenda for Change, Centre for Our Common Future, Geneva.

Lambin Jean-Jacques (2011) Quel Avenir pour le Capitalisme? Debat Actuels, Dunod, Paris.

Mäler Karl-Göran (1990) Sustainable development, Sustainable Development: Science and Policy. Conference Report, May, NAVF, Bergen pp. 8-12.

Martinez-Alier Joan (1995) Political Ecology, Distributional Conflicts and Economic Incommensurability, New Left Review, vol. 9, n. 3, pp. 295-323.

Mason Michael (1999) Environmental Democracy, Earthscan, London.

Meadows Dennis H., Meadows Donella L., Randers Jørgen, Behrens William III (1972) The Limits to Growth, Pan, London.

Moffatt Ian (1996) Sustainable Development: Principles, Analysis and Policies, Parthenon, London.

Ohno Taiichi (1978) Toyota Production System, Beyond Large-Scale Production, Productivity Press, New York.

Piketty Thomas (2013) Capital in the Twenty-First Century, Harvard University Press, Boston.

Porter Michael E., Kramer Mark R. (2011) Creating Shared Value, Harvard Business Review, JanFeb.

Porter Michael E., van der Linde Claas (1995) Green and Competitive: Ending the Stalemate, Harvard Business Review, Sept-Oct, pp. 119-134.

Redclift Michael (2005) Sustainable Development (1987-2005): An Oxymoron Comes of Age, Sustainable Development, vol. 13, pp. 212-227.

http://dx.doi.org/10.1002/sd.281

Reid David (1995) Sustainable Development: an Introductory Guide, Earthscan, London.

Sachs Woflgang (1999) Planet Dialectics, Zed, London. 
Schumacher Ernst Friedrich (1973) Small Is Beautiful: Economics as if People Mattered, Abacus, London.

Solability (2013a) The Global Sustainable Competitiveness Index 2013, (www.solability.com).

Solability (2013b) Corporate Sustainability 2013 Korea, $6^{\text {th }}$ Annual ESG Review, Strategic Sustainability, Corporate Governance, Energy (www.solability.com).

Strong Maurice (2000) Where on Earth Are We Going, Texere, New York.

Taylor Frederick W., Principles and Methods of Scientific Management, Harper Brothers, New York, 1911.

World Business Council for Sustainable Development (WBCSD) (2000) Eco-Efficiency: Creating more value with less impact, Geneva.

Workshop on Urban Sustainability (National Science Foundation) (2000) Towards a Comprehensive Geographical Perspective on Urban Sustainability, Rutgers University, NJ.

World Commission on Environment and Development (WCED) (President Gro Harlem Brundtland) (1987) Our Common Future, 20 March 1987, http://www.un-documents.net/ourcommon-future.pdf

\section{Notes}

${ }^{1}$ Our Common Future, by the World Commission on Environment and Development, 1987, p. 43. 